\title{
COMPARISON OF THE PRESENT VEGETATION WITH POLLEN-SPECTRA IN SURFACE SAMPLES FROM BROWNINGTON POND, VERMONT
}

\author{
Margaret Bryan Davis ${ }^{1}$ and John C. Goodlett ${ }^{2}$
}

\section{INTRODUCTION}

Pollen-bearing sediments found in lakes or bogs provide a record of past vegetation, presumably arranged in a stratigraphic column. Many pollen deposits contain essentially the same pollen types throughout. Thus description of a deposit depends largely upon a quantitative determination of the relative proportions of pollen types at various levels. Interpretation of pollen deposits assumes that frequencies of pollen types deposited reflect the complexion of the surrounding vegetation. Therefore, changes in frequencies of pollen types within the stratigraphic column are assumed to reflect changes in proportions of species or genera in the surrounding vegetation. These changes are often interpreted as the result of climatic change, one of the major factors affecting species composition of vegetation. For this reason, interpretations of pollen-bearing deposits are of great interest to students in such fields as glacial geology and paleoclimatology.

It has long been recognized, however, that the efficiency of pollen production and dispersal in different species of plants varies widely. A reasonable interpretation of a pollen spectrum can be made only if the relative pollen dissemination efficiency of each species is known. Attempts to estimate pollen production and pollen dispersal distance have been made in Europe (reviewed by Faegri and Iversen 1950) and in Japan (e.g. Tsukada 1958), but research in this aspect of pollen analysis has been largely neglected in North America. Pollen analysts here have tended to rely on European estimates of pollen production, a dangerous practice because the pollen production of congeneric species has been shown to vary (Pohl 1937). In a few areas, the present vegetation, studied at least in part quantitatively, has been compared to the pollen spectra in surface moss polsters or lake muds: the Great Smoky Mountains (Carroll 1943), Oregon (Hansen 1949), Alaska (Livingstone 1955), Alberta (Erdtman 1943) and Quebec (Potzger et al. 1956). However, pollen dissemination character-

\footnotetext{
${ }^{1}$ Division of Geological Sciences, California Institute of Technology, Pasadena, Calif.

${ }^{2}$ Harvard Forest, Petersham, Mass. Present address: Dept. of Geography, Johns Hopkins University, Baltimore, Md.
}

istics of most forest trees of New England are completely unknown.

This paper compares the present vegetation of the Memphremagog quadrangle in northern Vermont, an area containing both deciduous and coniferous tree species, with pollen spectra in samples of bottom muds now forming in lakes in that area. It describes 1) the methods and results of a survey of the vegetation of the quadrangle, 2) the methods and results of pollen analysis of mud samples, and 3) a comparison between these data. From the results a rough estimate is made of the relative pollen dissemination efficiency of some of the more common forest trees of the region. The significance of the results for the interpretation of fossil pollen spectra is discussed.

Colloquial names for tree species will be used in the discussion. For the convenience of the reader, a list of the names and their Latin equivalents (Fernald 1950) is given below:

Alder ................nus spp.

Black alder ........... Ilex verticillata

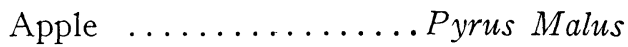

Arbor vitae ..........Thuja occidentalis

Black ash ............Fraxinus nigra

White ash ...........Fraxinus americana

Mountain ash ..........Pyrus americana

Large-toothed aspen .......Populus grandidentata

Trembling aspen ........Populus tremuloides

Beech ..............Fagus grandifolia

Gray birch ............ Betula populifolia

Paper birch ...........Betula papyrifera

Yellow birch ............ Betula lutea

Butternut ...........Juglans cinerea

Black Cherry ..........Prunus serotina

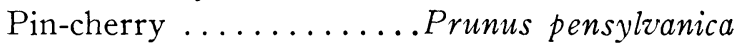

Chestnut ............Castanea dentata

Elm ............... Ulmus americana

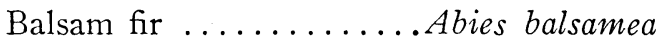

Hawthorn ........................

Hemlock ..........Tsuga canadensis

Hickory ............ Carya spp.

Hop-hornbeam ........ Ostrya virginiana

Larch ............... Larix laricina

Mountain maple ........Acer spicatum

Red Maple ............Acer rubrum

Striped maple ...........Acer pensylvanicum

Sugar maple ...........Acer saccharum 
Red Oak .............. Quercus rubra

Red pine .............Pinus resinosa

White pine ............Pinus Strobus

Balsam poplar ...........Populus balsamifera

Shadbush ............. Amelanchier

Black spruce ............Picea mariana

Red spruce ............. Picea rubens

White spruce ...........Picea glanca

Poison sumac ...........Rhus Vernix

Willow $\ldots . \ldots \ldots$..... Salix spp.

Geology and Climate of the Memphremagog Quadrangle

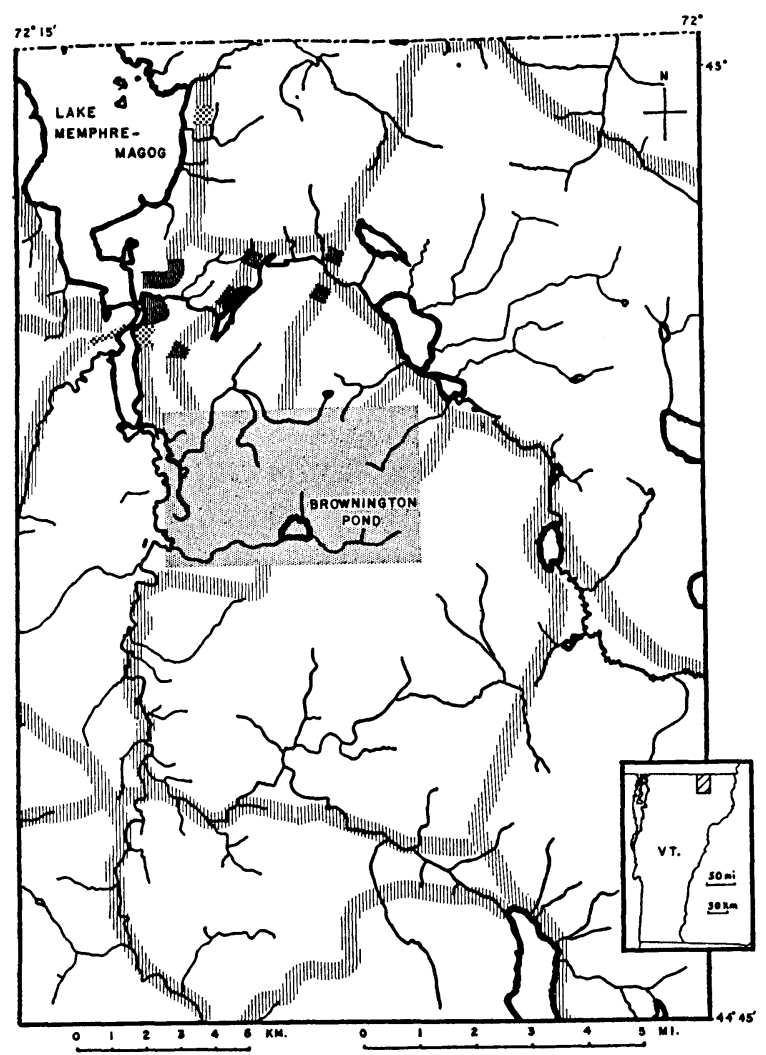

FIGURE । LEGEND

Area of detail map (Figure 2)

Plant traverses outside of sampled area (width of traversesexaggerated)

ㅁifili: = no ook trees observed

[and = one to few oak trees present on lawns

= red oak present, presumably wild trees; occurs both in forest stands and as scottered trees along field borders

Fig. 1. Outline map of Memphremagog quadrangle, showing the distribution of oak. Inset shows location of Memphremagog quadrangle (hachured area) in Vermont. Map is drawn from U. S. Geological Survey topographic map, $1: 62,500$.

The Memphremagog quadrangle (Fig. 1) comprises rolling hills underlain in large part by phyllite, schist, quartzite, slate and limestone and rising 300-500 ft above adjacent valleys (Doll 1951). Altitudes range from $682 \mathrm{ft}$ at Lake
Memphremagog to $2935 \mathrm{ft}$, the summit of Goodwin Mountain. This peak and Barton Mountain are underlain by granite and lie near the southern edge of the quadrangle. Granite also underlies a circular area about 5 miles in diameter that extends northward from Brownington Pond. The principal drainage is northwestward toward Lake Memphremagog and thence to the St. Lawrence River. Most of the region is mantled with calcareous drift or "boulder clay." Sand and gravel deposits lie in many valleys. The uplands have slopes that are commonly less than $20 \%$; many are less than $12 \%$. The region has a continental climate with cold winters. The mean January temperature at Newport, on the southern shores of Lake Memphremagog, for the years 19301958 has been $15.7^{\circ} \mathrm{F}$; the mean July temperature $67.2^{\circ} \mathrm{F}$; and the average annual precipitation 35.7 in. (M. W. Drew, personal communication).

\section{Vegetation}

Forests of sugar maple, birch, hemlock, beech and other deciduous species with occasional spruce, fir and arbor vitae occur on many slopes and on the summits of the hills and ridges. Stands of coniferous trees are common on the lower slopes and in the valleys. Young arbor vitae, spruce, fir and larch are frequently found in meadows and pastures. Apparently many of the coniferous stands are the first generation of trees on abandoned fields. This may explain their distribution in the valleys and on the gentler slopes that were suitable for clearing and cultivation.

Most of the cleared land in the quadrangle is used as pasture for dairy cattle. In addition, many of the forests show evidence of grazing by cattle and selective lumbering. The percentages of forested and non-forested land were estimated from the green overprint on the topographic map of the Memphremagog quadrangle, published by the U. S. Geological survey (scale $1: 62,500$, revised 1953). The quadrangle contains about $50 \%$ forested land, 45\% non-forested land, and 5\% open water.

A quantative study was made of the forests in the vicinity of Brownington Pond, near the center of the quadrangle. Sampling points within a 2 mile radius of the pond were selected by superimposing a $1 / 2$ in. grid on the map. Points that fell in green areas were located on the ground by inspection of the topographic map. Because of limited time we sampled only at the 18 forested points within the northern $180^{\circ}$ sector (Fig. 2). However, it is our impression, derived from traverses based upon 


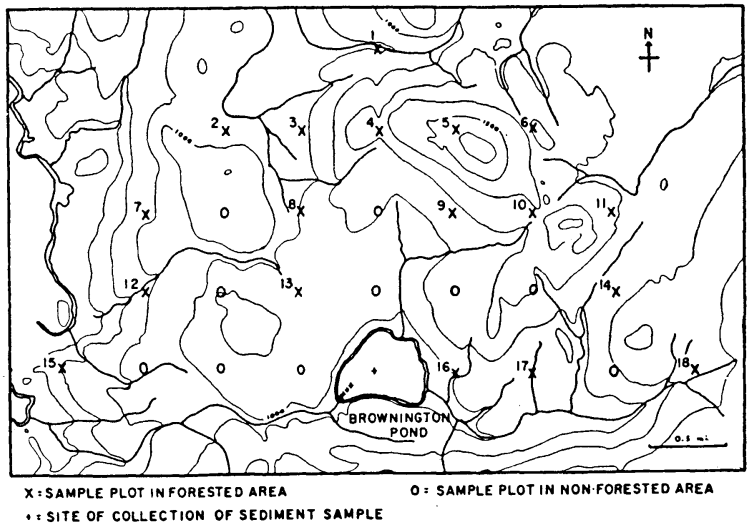

FIG. 2. Detail map of sample area, drawn from U. S. Geological Survey topographic map of the Memphremagog quadrangle. Contour interval $100 \mathrm{ft}$.

the road net (Fig. 1), that the vegetation in this sector is typical of much of the forest vegetation of the quadrangle. At each of the 18 sample points a circular 0.2 acre $\left(8712 \mathrm{ft}^{2}\right.$, about $\left.800 \mathrm{~m}^{2}\right)$ plot was marked off. All stems in the plot greater than 1 in. dbh (measured uniformly at $4.5 \mathrm{ft}$ above the ground surface) were identified, measured with calipers, and tabulated in the following categories: 1-2, 2-3, 3-4, 4-5, 5-6, 6-10, 10-20 in. dbh. Stems greater than 20 in. dbh were measured and recorded individually. At sample point 3 , saplings were so numerous that an estimate, rather than a count, was made for the deciduous tree stems in the smaller size categories. The data were later converted to basal area (cross-sectional area of stem at breast-height). Basal area is a more meaningful expression of the data for this study than stem frequency, because larger trees which have larger and higher crowns and presumably shed more pollen are assigned greater values than smaller trees. The total basal area of each sample plot, the number of stems counted, and the percentage of the total basal area contributed by each species are given in Table I and Figure 3. Spruce species were identified in the field by cone characters, but when cones were not available identifications were based on less reliable vegetative characters. For this reason spruce is identified only to genus in Figure 3 .

Sample plots indicated a highly diverse forest cover (Fig. 3 and Table I). The number of tree species per plot ranged from 4-14. Of the 31 species recorded, only 8 were found in as many as half of the 18 plots, and 9 species were found in only one or 2 plots. Not one of the species was found in all plots, although yellow birch and balsam fir each occurred in all but 3 . Only 5 species (balsam fir, arbor vitae, sugar maple, spruce and balsam poplar) constituted as much as $50 \%$ of
TABle I. Total basal area of each plot, the number of stems counted, and the percentage of basal area in sample plots contributed by species not shown in Fig. 3.

\begin{tabular}{|c|c|c|c|}
\hline 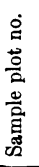 & 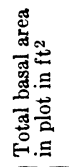 & 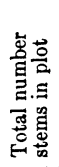 & Percentage basal area in plot: \\
\hline 1 & 42.05 & 99 & \\
\hline 2 & 33.31 & 183 & Pin-cherry 0.04 ; apple 1.28 \\
\hline 3 & 13.62 & 421 & Pin-cherry 3.40 \\
\hline 4 & 15.32 & 148 & White pine 1.07 ; hawthorn 0.74 \\
\hline 5 & 25.71 & 63 & Striped maple 1.67 \\
\hline 6 & 26.16 & 71 & Striped maple 8.45 \\
\hline 7 & 19.74 & 326 & Paper birch 10.20 ; apple 1.67 ; shadbush 0.06 \\
\hline 8 & 21.03 & 170 & Striped maple 0.81 \\
\hline 9 & 30.50 & 311 & Willow 0.19 ; black alder 4.92 \\
\hline 10 & 14.86 & 112 & Striped maple 0.25 ; black ash 7.73 \\
\hline 11 & 21.15 & 125 & Striped maple $0.32 ;$ pin-cherry $0.52 ;$ apple 0.06 \\
\hline 12 & 19.22 & 139 & $\begin{array}{l}\text { Black ash } 0.41 \text {; pin-cherry } 4.94 \text {; alder } 3.32 \text {; shadbush } \\
\quad 0.13 \text {; poison sumac } 0.06\end{array}$ \\
\hline 13 & 27.72 & 199 & \\
\hline 14 & 15.13 & 68 & \\
\hline 15 & 20.27 & 156 & Paper birch 0.87 \\
\hline 16 & 33.28 & 135 & Alder 0.75 ; shadbush 0.10 \\
\hline 17 & 7.12 & 153 & $\begin{array}{l}\text { Paper birch } 0.34 \text {; willow } 5.75 \text {; pin-cherry } 0.86 \text {; mountain } \\
\quad \text { ash } 0.52\end{array}$ \\
\hline 18 & 23.34 & 97 & Black cherry 1.49 \\
\hline
\end{tabular}

the basal area in any one plot. Stand diversity can be illustrated by another means. If the species found in each sample plot are arranged in descending order of basal area, and the minimum number of species required to make $75 \%$ of the basal area in the plot is recorded, it will be seen that the composition of no 2 plots is the same. The number of species required ranges from 1-4. Sugar maple provides the largest percentage of basal area in 5 plots, and spruce, arbor vitae, and hemlock in 2 plots each. In terms of total basal area in all 18 sample plots (Table II), the most abundant trees are the maples, arbor vitae, balsam fir, and the spruces, in that order. Each of these constitutes more than $10 \%$ of the total basal area.

Red pine, butternut, large-toothed aspen and oak trees were observed in the Memphremagog quadrangle, although none of these species was found at the sample points. Butternut trees were seen in field borders immediately north of the sample area, large-toothed aspen were seen on a few steep slopes, and red pines occasionally were observed on thick deposits of sand and gravel. Oak trees are apparently extremely rare in the Memphremagog area (Fig. 1). A few red oaks, and one mossy-cup oak (Quercus macrocarpa) were seen near farmhouses and in the villages. Red oaks are common shade trees in the city of Newport. Forest stands containing red oak trees were observed only on the steep sand banks, 200$400 \mathrm{ft}$ high, adjacent to South Bay of Lake 


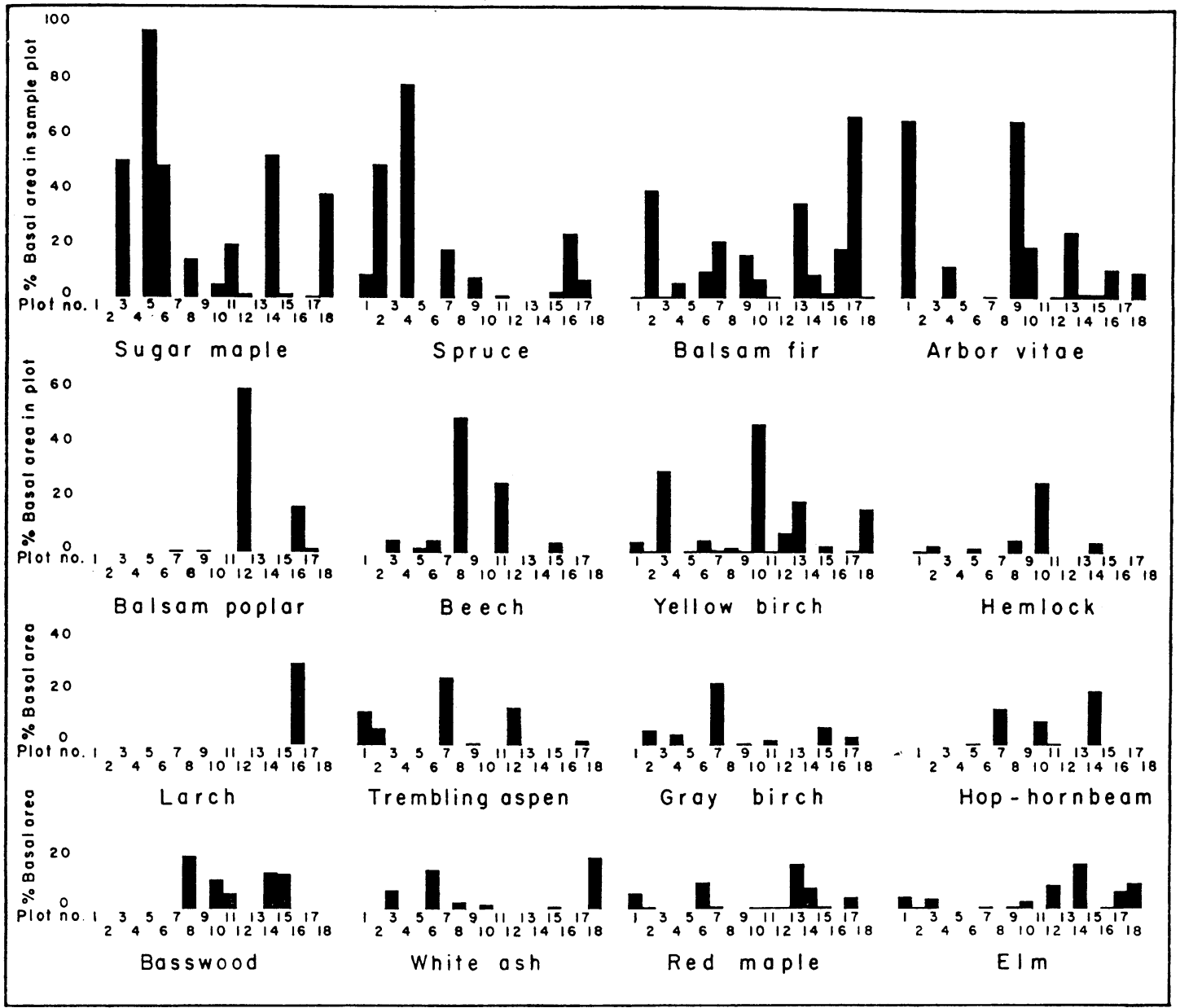

FIG. 3. Percentage of basal area in sample plots contributed by each species. Only those species that contributed at least 15 per cent of the basal area of one or more plots are shown.

Memphremagog, where at least $50 \%$ of the trees are red oaks. Other species are red pine, white pine, large-toothed aspen, trembling aspen, balsam poplar, red maple, sugar maple, striped maple, gray birch, paper birch, balsam fir, and arbor vitae. No oak was seen on the less extensive sand and gravel deposits along the rivers, or on steep, thinly-mantled bedrock slopes. Apparently oak does not grow naturally in this region except on coarse-grained, gravelly soils on extremely steep slopes. However, the possibility exists that steep slopes on higher hills in the southeastern part of the quadrangle, which were not thoroughly examined, support forest containing oak trees.

Of the tree species not found in any vegetation samples, oak is of the greatest interest because its pollen is found in all the surface samples, where it constitutes from $2.1-3.6 \%$ of the tree and shrub pollen. Only 8 of the tree and shrub pollen types exceed this maximum frequency of oak. Studies of the distribution of oak in New England (Good- lett, in preparation) suggest that oak is essentially absent from a wide area around Lake Memphremagog (Fig. 4). Unfortunately, the local distribution of oak in southern Quebec is not known, although small-scale distribution maps (Munns 1938; Little 1949) indicate that it is present.

Sample plots in unforested areas were not studied quantitatively. Four of them lay in meadows, one in a meadow with a few elm, 4 in meadows with young arbor vitae, spruce and fir, and one in a meadow overgrown with shrubs, young conifers and young deciduous trees.

\section{Pollen Analysis of Lake Mud}

Samples for pollen analysis were collected from Brownington Pond in the Memphremagog quadrangle and from Spectacle Pond, 15.5 miles to the southeast, in the Island Pond quadrangle. Samples \#1-5 were collected from the surface of the mud bottom in the shallower parts of 
TABLE II. Comparison of percentages of total basal area in the sample plots and percentages of pollen in the sediment samples.

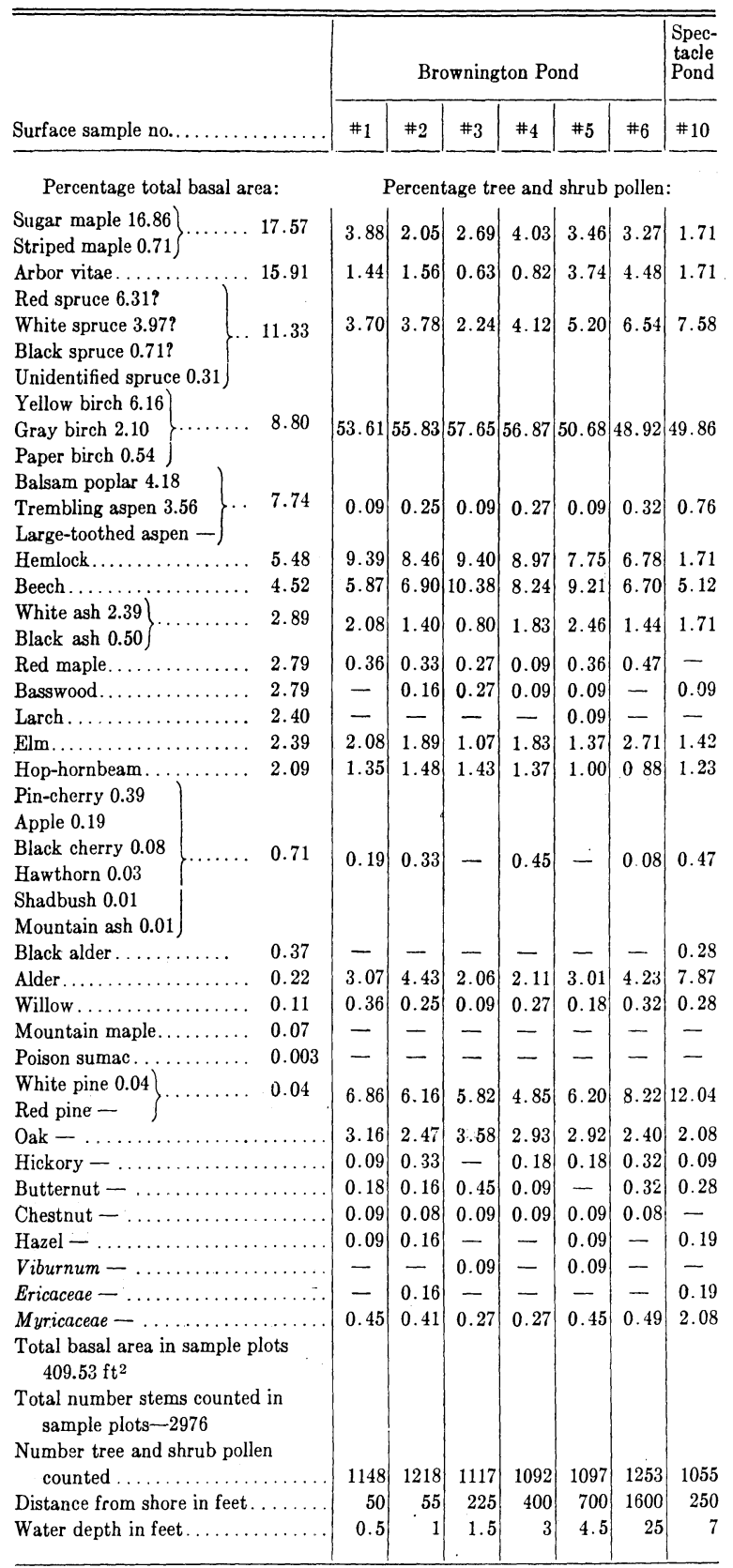

Brownington Pond and sample \#10 was collected from the surface of the mud bottom in Spectacle Pond. The samples were collected directly from the mud surface in $5 \mathrm{dr}$ glass vials. The approximate distance from shore at which the samples were taken and the water depth at each sampling site are indicated in Table II.

Sample \#6, mud from the center of Brownington Pond, was collected with a Livingstone borer by Davis and E. S. Deevey Jr. Soundings indi- cated a firm mud bottom $8 \mathrm{~m}(26 \mathrm{ft})$ below the water surface. The borer was lowered through the water to a depth of $7.3 \mathrm{~m}$ and a core of water and mud was taken from $7.3 \mathrm{~m}-8.3 \mathrm{~m}$ depth. A few minutes after the liner containing the core was brought to the surface, it was tilted to pour off water and loose mud in the upper part of the liner. The mud was caught in numbered $5 \mathrm{dr}$ vials as it was poured. These samples were designated \#6-9. The similarity of pollen frequencies in these samples indicated that mixing might have occurred when mud samples were poured from the liner. However, when they were tested for similarity by the chi-square test recommended by Faegri and Ottestad (Faegri and Iversen 1950), it was found that the frequencies of spruce, hemlock, birch and ash pollen in the 4 samples varied more than could be expected on the basis of chance if all 4 were from the same population $(0.05>\mathrm{P})$. The frequencies of spruce, hemlock and ash pollen in the 2 samples, \#6 and \#7, also varied significantly. It was decided, therefore, that complete mixing had not occurred, and that sample \#6, although perhaps contaminated to some extent with slightly older material, could be considered a sample of the mud surface.

Pollen was extracted from mud samples by flotation in bromoform (Frey 1951), deflocculation for $6 \mathrm{~min}$. with $10 \% \mathrm{KOH}$ in a boiling water bath, and acetolysis as described by Faegri and Iversen (1950). The residue was stained with neutral red and mounted in Mounting $\mathrm{Me}$ dium No. 8, obtained from the Tanglefoot Co., Grand Rapids, Mich. Pollen counts were made at 200x magnification. An apochromatic oil immersion lens was used for all critical identifications, including that of oak pollen. Pollen identifications were based on comparison with reference slides from herbarium collections. At least 1000 tree and shrub pollen grains were counted in each sample. The sum for calculating the percentages of these pollen types included only tree and shrub (and unidentified Rosaceae) pollen to allow comparison of pollen frequencies with frequencies of trees and shrubs in the forest survey. Percentages of herbaceous and aquatic plant pollen and spores were calculated as percentages of total tree, shrub and terrestrial herb pollen. The results of the analyses are shown in Tables II and III.

Pollen size as a means of identification.-Size measurements of birch, pine and spruce pollen in the sediment samples were made because size measurements are sometimes used for species identification of pollen types identifiable otherwise only to genus. The usual practice has been 


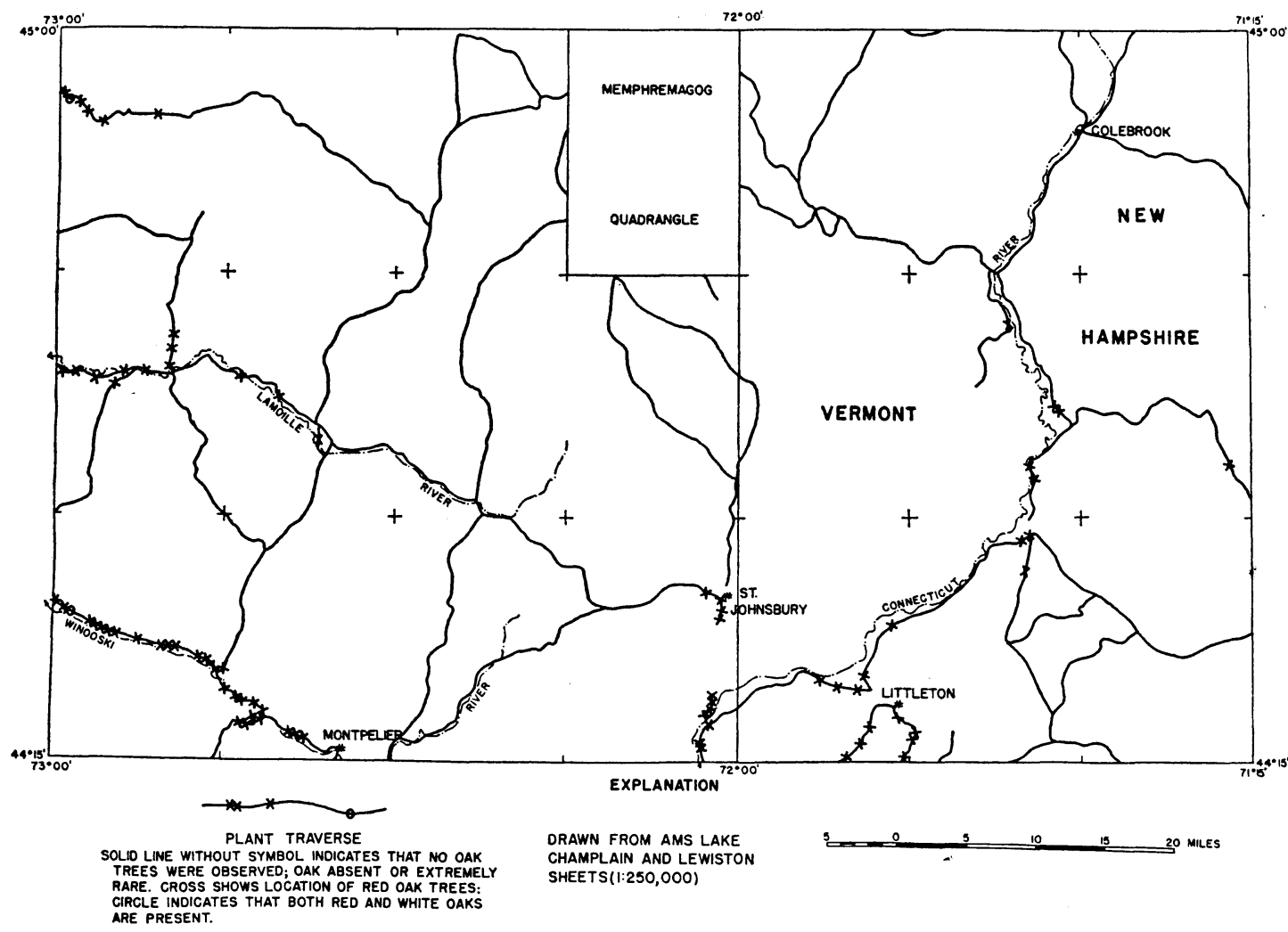

FIG. 4. Outline map of a portion of northern Vermont and New Hampshire, showing the distribution of oak in the region surrounding the Memphremagog quadrangle.

to compare the size distribution of a fossil pollen type with the size distribution observed in pollen prepared from living trees or herbarium specimens. Because size distributions of pollen from a single plant or from several plants of the same species are unimodal, bimodal size distributions of fossil pollen are usually interpreted to indicate the presence of pollen contributed by at least 2 species within the genus. The modal sizes are compared to the mean sizes of pollen observed in modern species, and identifications are made on this basis (Cain and Cain 1948). It was felt that the validity of this method could be tested by comparing the distributions of pollen size in the sediment surface samples with the mean pollen sizes described in the literature for species now living in the region.

The species of birch known in the Memphremagog quadrangle are yellow birch, gray birch and paper birch. In the sample plots yellow birch makes up to $70 \%$ of the basal area recorded for birch, gray birch $24 \%$, and paper birch $6 \%$. The mean size of pollen, treated with $\mathrm{KOH}$ and acetolyzed, observed for these species is $29.7 \mu$ (the average of the mean sizes of 100 grains measured in each of 10 collections from herbarium specimens) for yellow birch, $30.7 \mu$ ( 5 collections) for paper birch, and $25.4 \mu$ ( 4 collections) for gray birch (Leopold 1956). The birch pollen in our samples \#1 and \#6 is considerably smaller (Fig. 5 ). It ranges from $14.8 \mu$ to $29.6 \mu$; the modal size is $24.7 \mu$. Probably the pollen in the sediments is pollen from the 3 local species that has undergone a change in size as a result of laboratory treatment or of conditions of preservation. This hypothesis is supported by the fact that the pine and spruce pollen in the sediments is considerably smaller than modern pine and spruce pollen (see below). The mode of the size distribution of birch pollen in samples \#1 and \#6 may represent the modal size of yellow and paper birch pollen, and the asymmetry of the distribution may be due to the presence of gray birch pollen with a smaller modal size. In these samples, comparison of absolute pollen size apparently is not a reliable method for making species identifications.

White pine and red pine were the only pine species observed in the Memphremagog quadrangle. Measurements of the maximum internal diameter of acetolyzed pine pollen have been made by Cain and Cain (1948). They report 
TABLE III. Percentages of non-arboreal pollen types in the sediment analysis.

\begin{tabular}{|c|c|c|c|c|c|c|c|}
\hline \multirow[b]{2}{*}{ Surface sample no.. } & \multicolumn{6}{|c|}{ Brownington Pond } & \multirow{2}{*}{$\begin{array}{c}\begin{array}{c}\text { SPECTACLE } \\
\text { Pond }\end{array} \\
10\end{array}$} \\
\hline & $\#_{1}$ & $\# 2$ & $\# 3$ & $\# 4$ & $\# 5$ & $\# 6$ & \\
\hline & \multicolumn{7}{|c|}{ Percent total terrestrial plant pollen: } \\
\hline Total herbs. & 9.92 & $6.19 \mid$ & $6.92 \mid$ & $|8.16|$ & $|10.16|$ & 16.19 & 13.60 \\
\hline Total shrubs. & 3.58 & 3.76 & 2.33 & 2.44 & 3.44 & 4.15 & 9.42 \\
\hline Total NAP. & 13.50 & 9.95 & 9.25 & $|10.60|$ & $|13.60|$ & 20.33 & 23.01 \\
\hline Gramineae. & 3.66 & 3.39 & 1.83 & 3.20 & 4.01 & 6.35 & 6.06 \\
\hline Cyperaceae. & 2.11 & 1.62 & $0.67 \mid$ & $0.67 \mid$ & $|0.57|$ & 1.54 & 0.90 \\
\hline Ambrosia & 2.20 & 3.02 & 0.23 & 1.85 & 3.28 & 4.75 & 3.28 \\
\hline Xanthium-type . & - & 0.07 & - & 0.25 & - & 0.07 & - \\
\hline Artemisia-type. & 0.08 & 0.07 & 0.25 & 0.08 & 0.24 & 0.20 & 0.16 \\
\hline Tubulifloreae... & 0.24 & 0.37 & - & 0.25 & 0.24 & 0.60 & 0.16 \\
\hline Ligulifloreae... & - & - & 0.08 & - & 0.08 & 0.07 & 0.16 \\
\hline Chenopodiaceae. . & 0.16 & 0.22 & - & $\mid 0.17$ & - & 0.13 & 0.16 \\
\hline Rumex. & 1.30 & 1.18 & 1.33 & 1.26 & 1.39 & 1.81 & 2.05 \\
\hline Plantago major-type. & 0.08 & - & - & - & 0.16 & 0.20 & - \\
\hline Plantago lanceolata-type. & - & 0.15 & - & - & 0.08 & 0.07 & 0.16 \\
\hline Plantago sp... & - & - & - & - & - & 0.13 & - \\
\hline Thalictrum. & 0.16 & - & - & 0.17 & - & 0.07 & 0.24 \\
\hline Caryophyllaceae & - & 0.07 & - & - & - & $\begin{array}{llll}0 & 13 & 13\end{array}$ & - \\
\hline Leguminosae. & - & 0.07 & $\begin{array}{ll}0 & 17\end{array} \mid$ & - & - & - & 0.08 \\
\hline Umbelliferae. & - & - & 0.08 & - & - & - & 0.08 \\
\hline Urticaceae..... & - & - & - & - & 0.08 & 0.07 & - \\
\hline Galium-type... & - & - & - & - & - & - & 0.08 \\
\hline $\begin{array}{l}\text { Number terr. strial plant } \\
\text { pollen counted }\end{array}$ & 230 & & & & & & \\
\hline pollen included in sum: & & $135 i$ & 1200 & 1189 & 1221 & 1495 & 1221 \\
\hline Unknown. . & $\begin{array}{lll}024 & -1\end{array}$ & $\begin{array}{llll}0 & 0 & i\end{array} \mid$ & $\begin{array}{lll}0 & 58\end{array}$ & 0.75 & 0.08 & 0.60 & 0.57 \\
\hline Ranunculaceae. & 0.16 & - & 0.17 & $|0.08|$ & 0.41 & $|0.40|$ & 0.33 \\
\hline Typhaceae. & - & $0.07 \mid$ & 0.08 & 0.25 & $\mid 0.16$ & - & 0.33 \\
\hline Nymphaea. & 0.08 & - & - & - & - & 0.07 & - \\
\hline Nuphar. & 0.08 & 0.07 & - & 0.17 & \begin{tabular}{|ll|l|}
0 & 24
\end{tabular} & 0.13 & 0.08 \\
\hline Ponte & $\begin{array}{llll}0 & 08\end{array}$ & - & 0.08 & $\mid \begin{array}{lll}0 & 0 & 8\end{array}$ & $\mid 0.08$ & 0.13 & - \\
\hline Pot rmogeton. & 0.08 & 0.15 & 0.08 & 0.08 & $\begin{array}{lll}0 & 08\end{array}$ & 0.07 & 0.08 \\
\hline Brasenia..... & - & $\left|\begin{array}{lll}0 & 07\end{array}\right|$ & - & - & - & - & - \\
\hline Myrioph jllum & - & - & $\left|\begin{array}{lll}0 & 08\end{array}\right|$ & $\begin{array}{lll}0 & 08\end{array}$ & $\mid \begin{array}{lll}0 & 08\end{array}$ & $\left|\begin{array}{lll}0 & 0 \bar{i}\end{array}\right|$ & - \\
\hline Lycopodium. & 0.41 & 022 & $\begin{array}{lll}0 & 58\end{array}$ & \begin{tabular}{ll|l}
0 & 17
\end{tabular} & $\mid 0.24$ & \begin{tabular}{|ll|l|} 
& 67
\end{tabular} & 0.74 \\
\hline Lycopotium luci.iulum-type. . & $\begin{array}{lll}0 & 16\end{array}$ & 0.22 & 0.17 & 0.25 & $\left|\begin{array}{lll}0 & 0 & 8\end{array}\right|$ & 0.40 & 0.49 \\
\hline Selaginella. & - & - & - & - & - & $\begin{array}{lll}0 & 0:\end{array}$ & - \\
\hline Isoetes. . & - & - & 0.08 & - & $\begin{array}{lll}0 & 24\end{array}$ & $\left|\begin{array}{lll}0 & 27\end{array}\right|$ & $0+1$ \\
\hline Sphagrum. & $\begin{array}{lll}0 & 08\end{array}$ & $0.0 ;$ & - & c. 08 & 0.08 & \begin{tabular}{|ll|l|}
0 & 0 & 7
\end{tabular} & $05 i$ \\
\hline Filices..... & 1.71 & $1.3 i$ & 0.75 & 1.09 & $\begin{array}{lll}0 & 82\end{array}$ & $1.8{ }^{\circ}$ & $28 \pi$ \\
\hline Dryopteris Linnaeana-type. & - & - & - & - & - & - & 0.08 \\
\hline Osmunda. . & 0.16 & 0.22 & 0.17 & - & 0.16 & 0.20 & 0.24 \\
\hline Unknown spores. & 0.16 & 0.15 & - & - & - & 0.40 & 0.33 \\
\hline
\end{tabular}

a mean size of $50.38 \mu(\sigma=4.03 \mu)$ for white pine (9 collections) and $46.00 \mu(\sigma=2.85 \mu)$ for red pine (10 collections). The size distribution of the maximum internal diameter of pine pollen in sample \#6 (Fig. 5 ) has 2 modes, $37.0 \mu$ and $42.0 \mu$. As in birch, the absolute size is smaller than that observed for modern pollen. The distribution shows, however, that bimodal size-frequency distributions can occur in mixed populations of pollen from white and red pine. Bimodal size frequency distributions of pine pollen in fossil material are often interpreted to indicate the presence of the pollen of jack pine (Pinus banksiana), which has a mean size of $45.9 \mu$ (Cain and Cain 1948). However, it is clear from these data that both red and jack pine, as Cain and Cain's measurements have already indicated, must be considered in the interpertation of bimodal distributions of fossil
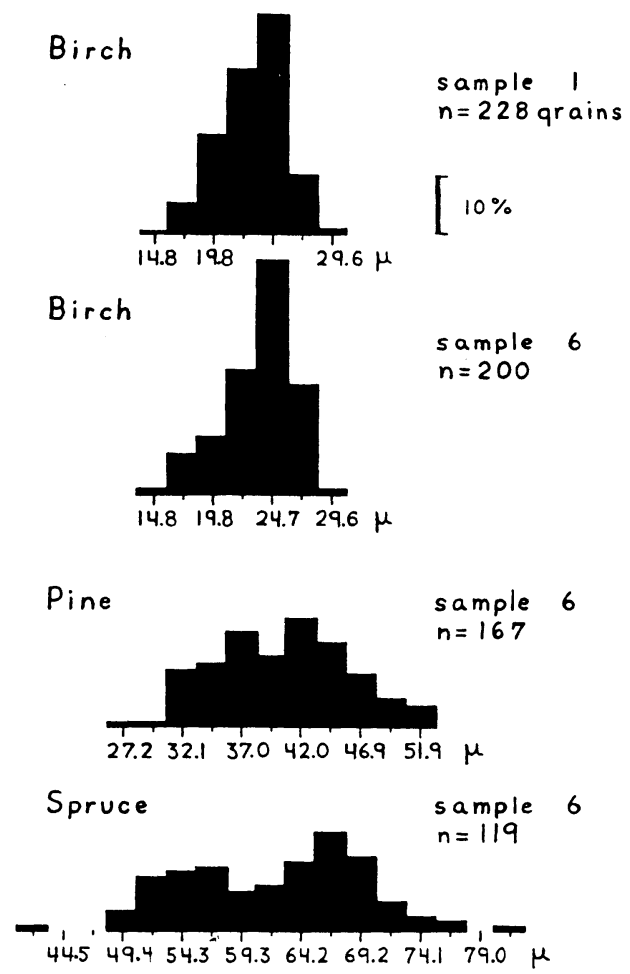

FIG. 5. Size distributions of birch, pine and spruce pollen in sediment samples.

pine pollen.

The maximum internal diameter of spruce pollen in sample \#6 was also measured (Fig. 5). Size measurements of pollen, treated with $\mathrm{KOH}$ and acetolyzed, are available for the 3 species that occur in the Memphremagog quadrangle. The mean pollen size for white spruce ( 5 collections) is $80.36 \mu(\sigma=5.45 \mu)$, red spruce (8 collections) $76.59 \mu \quad(\sigma=4.73 \mu)$, and black spruce (3 collections) $62.17 \mu(\sigma=4.28 \mu)$ (Cain 1948; S. A. Cain and S. T. Andersen, personal communication). The size distribution of spruce pollen in sample \#6 is bimodal, with modes at about $54 \mu$ and $67 \mu$. Although the absolute size of the pollen is smaller than in modern pollen preparations it is likely that the mode at $67 \mu$ represents white and red spruce pollen, and the mode at $54 \mu$, black spruce pollen. The bimodality of the distribution was unexpected because of the low frequency of black spruce in the forest $(6 \%$ of the basal area recorded for spruce in the sample plots). However, spruce pollen in samples \#5 and \#7, measured several months later, displayed unimodal size distributions, skewed to the larger size classes. Bimodality in sample \#6 may be the result of 
statistical error or of an unusually large proportion of black spruce pollen in that sample. A1though the data seem to indicate that black spruce is better represented in the sediments than the other spruce species, surface samples from Quebec (Potzger et al. 1956) indicate the reverse. The possibility that the spruce species differ in pollen production should be investigated, because changes in the percentages of fossil spruce pollen in pollen zone $\mathrm{A}$ in Massachusetts have been correlated with changes in the modal pollen size (Davis 1958). If the spruce species vary greatly in pollen dissemination efficiency, the changes in pollen frequency may have resulted from a change in the relative abundance of the species, rather than from a change in the absolute abundance of the genus in the vegetation.

Comparison of the Pollen Frequencies and the Present Vegetation

Results of the forest survey and the pollen analyses are summarized in Figure 3 and Tables I, II and III. Two outstanding facts emerge from a comparison of these data. First, although there are large local differences in the composition of the vegetation, the pollen content of sediments now forming in Brownington Pond shows only slight differences. Even the spectrum from Spectacle Pond, about 15 miles from Browning Pond, is similar. Second, the pollen composition of the sediments shows little relation to the composition of the vegetation. Nearly all the tree species observed in the present vegetation are represented in the sediments, but quantitative relations are almost completely lacking. For most species and genera the percentages of total tree and shrub pollen in the surface samples are strikingly different from the percentages of total basal area in the forest stands (Fig. 6). The forest survey indicates that the maples, arbor vitae, balsam fir, spruce, birch and poplar constitute about $75 \%$ of the forest stands. Although the sample is smaller than desirable in a region of such diverse vegetation, even casual observation of the forest would support this conclusion. In contrast to the forest survey, birch, beech, hemlock and pine are the most abundant pollen types in all the samples.

To use our data to estimate relative efficiencies of pollen dissemination, we must assume that most of the pollen deposited at Brownington Pond had its source within the Memphremagog quadrangle. This cannot be proved on the basis of the pollen spectra because much of northern New England and southern Canada has a similar flora, at least

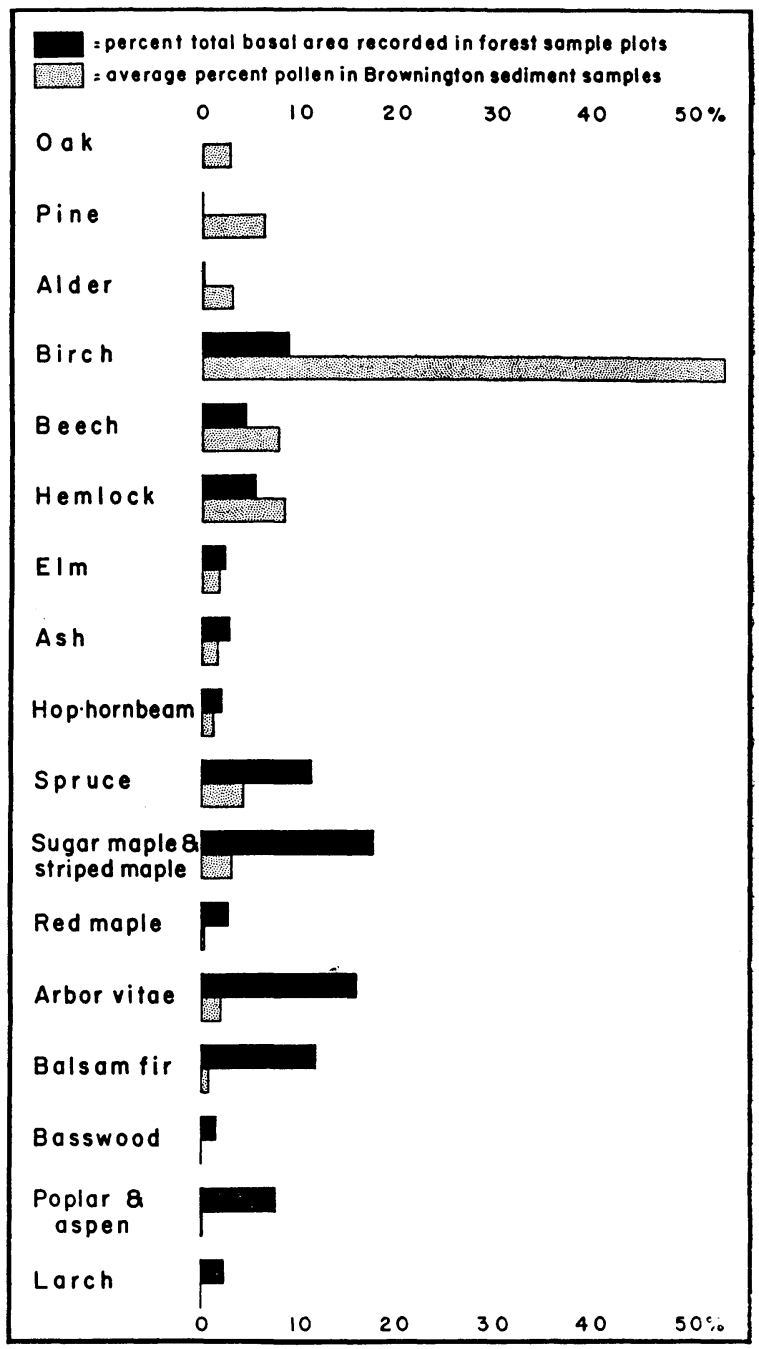

FIG. 6. Comparison of the percentage total basal area recorded in sample plots and the average pollen percentage in sediments from Brownington Pond of seventeen species and genera.

on the generic level. However, in regions of widely divergent vegetation, series of surface peat and humus samples indicate that in forested regions the majority of the pollen is contributed by trees within a few miles of the sampling station (Tsukada 1958). In partially forested or nonforested regions the frequency of tree pollen transported from a "long distance" is much higher. For example, in Norway the frequency of "longdistance" tree pollen as opposed to "local" tree pollen is thought to be roughly the same as the frequency of non-arboreal pollen (Faegri and Iversen 1950). This generalization has not yet been tested in eastern North America, but if it is true we may expect that $80-90 \%$ of the tree pollen at Brownington Pond is from "local" trees, and $10-20 \%$ has been transported from trees growing at a "distance." Unfortunately the area 
regarded as "local" cannot be easily defined and depends upon the relative buoyancy of each pollen type. According to Faegri and Iversen (1950) pollen is only occasionally transported hundreds of miles. They believe that the natural limit of pollen transport is $50-100 \mathrm{~km}$ (30-60 miles) and that the great majority of pollen falls to the ground long before it has traveled that distance.

Considering the uncertainty of the origin of the pollen and the small size of the forest sample, it is not possible on the basis of our data to rank the trees according to their pollen dissemination efficiency. We can only provide a rough rankorder by observing those genera that are overrepresented in the sediments (according to our data) and those that are underrepresented. It should be emphasized that these relations will not necessarily hold in other pollen spectra even though other variables are equal, because the pollen percentages are relative. For example, genera that are overrepresented here may be underrepresented in regions where genera with high pollen production are more abundant.

Overrepresented pollen types.-Oak pollen is highly overrepresented in the sediments. The frequencies are similar in all samples, suggesting that oak pollen is readily dispersed by wind. A1though European species have generally been considered moderate to poor pollen producers, several authors have noted that the pollen is readily transported by air currents (Hesmer 1933; Vareschi 1935; Dyakowska 1936). Similar observations have been made in Japan (Tsukada 1958). Potzger et al. (1956) found oak pollen in surface samples in Quebec that were collected at least 5 miles from the nearest stands of oak, and Carroll (1943) observed oak pollen in moss polsters collected in the Great Smokies at an elevation 1,950 ft higher than the nearest oak trees. The relatively high frequencies of oak pollen in samples from the Memphremagog quadrangle, where oak trees are extremely infrequent, suggest that red oak in this region is a heavy pollen producer. Another possibility is that the high frequencies are due to long-distance transport, but oak is infrequent in a wide area surrounding the quadrangle (Fig. 4). The characteristics of pollen dissemination in other species of oak, and in red oak in other parts of its range, should be studied further.

Pine is also overrepresented. The percentage is highest in sample $\# 10$, as was expected since red and white pine are common along the shore of Spectacle Pond. However, it is surprising that there is so little difference in the pine pollen per- centages at this site and at Brownington Pond, where pine is infrequent. Pollen produced by the few pine in the area apparently is readily dispersed and falls in an even rain over a wide area. Dyakowska (1936) has shown that pine pollen is buoyant in air, and surface sample studies have shown that it is transported over long distances (Hesmer 1933; Vareschi 1935; Lüdi 1937; Carroll 1943; Aario 1944; Potzger et al. 1956). The high frequencies of pine pollen in comparison to the low frequency of pine in the forest probably indicate that red and white pine, like European pine species (Pohl 1937), produce pollen in great quantity.

Birch and alder are also highly overrepresented, although the differences in per cent basal area and per cent pollen are not so striking as in pine and oak. Potzger et al. (1956) found in Quebec that birch was overrepresented in pollen spectra somewhat similar to ours.

Proportionately represented pollen types.-Pollen percentages of hemlock and beech slightly exceed the per cent basal area recorded for these species, and the pollen percentages of ash, elm, spruce and hop-hornbeam are equal to or slightly less than their per cent basal area. Within the limits of accuracy of this study, all these genera or species are about the same in their representation in the pollen spectra as compared to their representation in the forest.

Underrepresented pollen types.-The percentages of maple, arbor vitae, fir, poplar, larch and basswood pollen all are much lower than the per cent basal area recorded in the forest. Similar results have been obtained by Potzger et al. (1956) in Quebec, where arbor vitae, larch and mountain maple were found to be poorly represented in surface pollen spectra. They also found that although the basal area per acre of balsam fir and spruce (mostly black spruce) was approximately equal, the ratio of fir to spruce pollen was $2: 3$. In the Memphremagog quadrangle the basal area of balsam fir and spruce (mostly red and white spruce) is again approximately equal; the ratio of fir to spruce pollen at Brownington Pond is in most cases about $1: 4$. Balsam fir appears consistently less well represented in pollen samples than spruce, regardless of which spruce species are considered. Fir species may differ in pollen production, however. In an area in the Great Smokies where the basal area of Fraser's fir (Abies Fraseri) was two thirds as great as spruce (red spruce), the pollen frequencies of fir and spruce were approximately equal (Carroll 1943).

The percentages of arbor vitae pollen are low $(4.5 \%$ maximum) and vary from one sample 
to another. Arbor vitae is abundant in forests near the shore, yet pollen percentages are lower in sample \#10 and in the shallow water samples from Brownington Pond than they are in samples from deeper water. Possibly arbor vitae pollen is less resistant to decay than other pollen types (Hesmer 1933). As the mud surface beneath shallow water is occasionally exposed to oxidative conditions that promote pollen degradation, the frequencies of arbor vitae pollen in shallow water samples may be reduced, relative to other pollen types, by decay under oxidative conditions.

Other tree and shrub pollen types.--Pollen of butternut, hickory and chestnut was found in low frequencies in most surface samples, although these genera were not observed in the sample plots. A few butternut trees were observed along roadsides, but hickory and chestnut were not seen in the quadrangle and are either infrequent or absent. The efficiency of pollen dissemination in these species should be tested in areas where they occur in greater abundance.

Rosaceous trees, willow, black alder, hazel, Viburnum, Ericaceae, Myricaceae and poison sumac occurred in low frequencies in the sample plots or were found as pollen in the sediments. The frequencies are too low to allow an estimate of their relative representation in the pollen spectra.

Non-arboreal pollen types.-It is estimated that $45 \%$ of the Memphremagog quadrangle is nonforested. Most of the non-forested land is used as pasture, and supports a rich growth of sedges and grasses. Weeds are common along roadsides and in meadows. The herbaceous flora, however, is poorly represented as pollen in the sediments. Percentages vary from $6 \%$ of total pollen in samples taken near the shore of Brownington Pond, to $16 \%$ in sample \#6 from the center of the lake. Very little herbaceous pollen, apparently, comes from the aquatic vegetation near the shore. The pollen of shallow water rushes and sedges in Brownington Pond either is produced in minute quantities or its proportion in the sediments is reduced by tree pollen. The variations in non-arboreal pollen percentages from one sample to another are in contrast to the uniformity of the tree pollen percentages. There are several possible explanations: 1) During collection, sample \#6, which was collected with a Livingstone borer, could have been mixed with older sediment with a high NAP (non-arboreal pollen) frequency. However, the mud underlying sample \#6 has been analyzed and found to have the same or lower NAP frequency, and statistical tests indicate that mixing was not complete. 2) The frequency of NAP may have been reduced by differential degradation, as has been suggested in the case of arbor vitae. Lüdi (1937) has suggested that non-arboreal pollen is less resistant to decay than arboreal pollen. However, this explanation is not satisfactory because sample \#10, in which the pollen was in noticeably poor condition, has a higher NAP frequency ( $13.6 \%$ herbs, $9.4 \%$ shrubs) than any of the samples from Brownington Pond. 3) The proportion of NAP in sediments near the shore has been reduced by pollen from nearby trees. This assumption fails to explain the high NAP percentages in the sample taken near the shore of Spectacle Pond. 4) The patchy distribution of forests may affect the dispersal of non-arboreal pollen, because herbaceous pollen is shed near the ground and dispersed by local air movements (Hesmer 1933) ${ }^{3}$. The waters near the shore of Brownington Pond may be protected by nearby forests from the local winds that carry NAP. The effect of a forest near the shore may be similar to the vertical screening effect produced by forest canopies (Dengler 1955; Potzger et al. 1956). In contrast, Spectacle Pond is relatively unprotected because it is bordered on one side by a meadow. Possibly the pollen deposited at an exposed site such as the center of a large lake is derived from a larger area than pollen deposited at sites protected from wind by nearby forest.

Significance of Study for Interpretation of Fossil Pollen Diagrams

In the comparison of the present vegetation of the Memphremagog quadrangle with the pollen in surface samples, little quantitative relation was. found between the frequencies of pollen types and the frequencies of species in the vegetation. The complexion of past vegetation cannot be deduced accurately from fossil pollen spectra before the relations between the present pollen rain and the present vegetation are better understood. An understanding of these relations depends upon greater knowledge of at least four variables: 1) differences in amounts of pollen produced by different species, which may themselves show genetic, environmental and ontogenetic variations; 2) differences in pollen transport distances, which vary widely because of the physical properties of the pollen grains themselves, and are influenced by topography, vegetation cover, and atmospheric conditions that differ from year to year; 3 ) differ-

${ }^{3}$ Rowley (1955), however, found similar numbers of grass pollen in pollen traps located about $800 \mathrm{ft}$ apart, one in a meadow, the other on the forest floor. 
ences in preservation and patterns of deposition of pollen types, which may be affected both by the properties of the different kinds of pollen as well as by the characteristics of the collecting basins; and 4) local variations in species distribution and frequency of the present vegeation. Unfortunately, this study can make little contribution to solution of these problems, and can only emphasize their existence.

Furthermore, large local variations in the forests of the Memphremagog region produce essentially uniform pollen spectra in the lake sediments. This uniformity suggests that estimates of the local variations of past vegetation probably cannot be made on the basis of pollen diagrams. The pollen diagrams will record the contribution of each species that grew in the region from which the pollen came, rather than the contribution of presumed plant communities. Species with quite different ecological requirements will occur together in pollen spectra if the region contributing pollen is large.

Climatic interpretations of pollen diagrams are based on the presence or absence of "indicator species" and on changes in pollen frequencies. The presence or absence of pollen has little meaning, however, unless pollen dispersal characteristics are known. Similarly, interpretation of changes in pollen frequencies depends on knowledge of the size of the region that contributes pollen. The pollen deposited in Brownington Pond, for example, may have come from trees within a 5 or a 50 mile radius. Changes of pollen frequency in the sediments of the lake may thus represent changes in the vegetation of an area ranging in size from 75-7500 sq miles. Interpretations of such changes will remain entirely speculative until the meanings of the terms "regional vegetation" and "regional pollen rain" are clarified by many comparative studies of the present vegetation and the present pollen rain in North America.

The complexity of the American flora adds difficulties to the solution of the problems we have outlined. Much of the data in the literature cannot be applied to North America because congeneric species vary in pollen production and pollen bouyancy. Even American estimates of pollen production, if they are based on one species or a mixed population of species, cannot be applied to generic pollen types. If species within a genus show extreme variation in pollen production, it will be difficult or impossible to interpret changes in frequency of fossil pollen types unless species identifications are made.
It is our hope that this study will prompt further research into the basic principles of pollen analysis. Clarification of problems outlined here will make future analyses of fossil pollen deposits more meaningful, and will increase the value of previous work.

\section{Sum MARY}

The vegetation of the Memphremagog quadrangle in northern Vermont has been surveyed in some detail. Quantitative studies of 18 sample plots in the vicinity of Brownington Pond indicate a highly diverse forest vegetation. Pollen was analyzed in samples of the mud bottom of Brownington Pond and of Spectacle Pond, 15.5 miles distant. The tree pollen percentages in all the samples were closely similar, indicating that the tree pollen rain in the region is fairly uniform. Variations in NAP percentages may indicate that the non-arboreal pollen rain is not uniform because it is distributed by local air currents. Pollen frequencies of tree species show little quantitative relation to the basal area percentages recorded in the forest sample plots. On the basis of comparison of the basal area percentages in the sample plots and the percentage pollen in the sediment samples, the more common tree and shrub species of the region have been divided into 3 groups according to relative representation in the pollen sum. In order of decreasing representation, the groups are: 1) red oak, pine ( 2 spp.), alder and birch (3 spp.) ; 2) beech, hemlock, elm, spruce (3 spp.), ash (2 spp.) and hop-hornbeam; and 3 ) maple (4 spp.), arbor vitae, balsam fir, poplar (3 spp.), larch and basswood.

Size measurements were made of the pollen of birch, pine and spruce and compared to the mean size of pollen of the species that now occur in the region. The size-frequency distribution of yellow, white and gray birch pollen was unimodal and skewed to the larger size classes, and the distributions of both red and white pine pollen and white, red and black spruce pollen were bimodal.

\section{Acknowledgments}

The authors wish to express their sincere appreciation to E. S. Deevey, Jr. for supporting this project and aiding in the collection of surface samples; to Milton W. Drew, U. S. Airway Observer, for providing climatic data for Newport, Vt.; to J. G. Ogden III for sending needed reference slides of Quercus rubra pollen; to Heinz A. Lowenstam, California Institute of Technology, for providing laboratory space; and to Charles S. Denny and John $T$. Hack for reading the manuscript and offering valuable criticism. Field work for this study was supported by the National Science Foundation, research grant number G-4802, and by the Maria Moors Cabot Foundation for Botanical Research. 


\section{REFERENCES}

Aario, L. 1944. Úber die pollenanalytischen Methoden zur Untersuchung von Waldgrenzen. Geol. Fören. Förhdl. 66: 337-354.

Cain, S. A. 1948. Palynological studies at Sodon Lake, I. Size-frequency study of fossil spruce pollen. Science 108: 115-117.

Cain, S. A., and Cain, L. G. 1948. Palynological studies at Sodon Lake, II. Size-frequency studies of pine pollen, fossil and modern. Amer. Jour. Botany 35: 585-591.

Carroll, G. 1943. The use of Bryophytic polsters and mats in the study of recent pollen deposition. Amer. Jour. Botany 30: 361-366.

Davis, M. B. 1958. Three pollen diagrams from central Massachusetts. Amer. Jour. Science 256: 540570.

Dengler, A. 1955. Utber den Pollenflug und seine Ausfilterung innerhalb von Waldbeständen. Z. Forstgenetik, Frankfurt a. M. 4, H. 4/5: 110-113.

Doll, C. G. 1951. Geology of the Memphremagog quadrangle and the southeastern portion of the Irasburg quadrangle, Vermont. Vermont Geological Survey Bull. 3: 113 pp.

Dyakowska, J. 1936. Researches on the rapidity of the falling down of pollen of some trees. Acad. Polonaise Sci. et Let., Cl. Sci. Math. et Nat., Bull. III, B. I : 155-168.

Erdtman, G. 1943. An introduction to pollen analysis. Waltham, Mass., Chronica Bontanica Company.

Faegri, K., and Iversen, J. 1950. Text-book of modern pollen analysis. Copenhagen, Ejnar Munksgaard.

Fernald, M. L. 1950. Gray's Manual of Botany, 8th ed. New York, American Book Company.

Frey, D. G. 1951. Pollen succession in the sediments of Singletary Lake, North Carolina. Ecology 32: 518-533.
Hansen, H. P. 1949. Pollen content of moss polsters in relation to forest composition. Amer. Midl. Naturalist 42: 473-479.

Hesmer, H. 1933. Die naturliche Bestockung und die Waldentwicklung auf verschiedenartigen märkischen Standorten. Zeit. für Forst-und Jagdwesen 65: 505540, 569-606, 631-651.

Leopold, E. B. 1956. Pollen size-frequency in New England species of the genus Betula. Grana Palynologica (N. S.) 1: 140-147.

Little, E. L., Jr. 1949. Important forest trees of the United States. In Trees, Yearbook of Agriculture: 763-814. Washington, U. S. Government Printing Office.

Livingstone, D. A. 1955. Some pollen profiles from arctic Alaska. Ecology 36: 597-600.

Lüdi, W. 1937. Die Pollensedimentation im Davoser Hochtale. Ber. geobot. Inst. Rübel 1936: 365-470.

Munns, E. N. 1938. The distribution of important forest trees of the United States. U. S. Dept. Agriculture Misc. Pub. 287.

Pohl, F. 1937. Die pollenerzeugung der Windblütler. Beih. Bot. Centralb1. A 56: 365-470.

Potzger, J. E., Courtemanche, A., Sylvio, Br. M., and Hueber, F. M. 1956. Pollen from moss polsters on the mat of Lac Shaw bog, Quebec, correlated with a forest survey. Butler Univ. Bot. Stud. 13: 24-35.

Rowley, J. R. 1955. A study of recent pollen at Lake Itasca Biological station. Minnesota Acad. of Science 23: $50-60$.

Tsukada, M. 1958. Untersuchungen über das verhältnis zwischen dem Pollengehalt der Oberflächenproben und der Vegetation des Hochlandes Shiga. Jour. Inst. Polytechnics, Osaka City Univ. Series D 9: 217-234.

Vareschi, V. 1935. Pollenanlysen aus Gletschereis. Ber. Geobot. Inst. Rübe1 1934 : 81-99. 